\title{
KOMPOS DARI KOYORAN DAN BULU SEBAGAI SOLUSI PENCEMARAN LIMBAH PADAT LINGKUNGAN INDUSTRI KULIT DI KAB. MAGETAN
}

\author{
Sunaryo, Hery Koesmantoro, Sigit Gunawan
}

\begin{abstract}
ABSTRAK
Unit Pelaksana Teknis (UPT) Industri Kulit dan produk Kulit Magetan menampung 35 perusahaan dan 115 pengrajin penyamak kulit, dari proses ini dihasilkan limbah padat dalam bentuk koyoran dan bulu dalam jumlah yang cukup besar. Karakteristik limbah tersebut tidak mudah terurai, berbau spesifik sehingga cukup mengganggu lingkungan sekitar yang berdampak terhadap protes masyarakat. Badan Lingkungan Hidup Kabupaten Magetan dan Institusi terkait harus bertanggung jawab untuk melakukan pembinaan agar permasalahan yang terjadi tidak semakin meluas.

Koyoran dan bulu dilakukan fermentasi, dengan dikontrol pH dan suhu yang normal untuk mendapatkan pupuk organik yang baik, dengan dilakukan pemeriksaan Nitrogen, kalium dan Phosphat. Sampel penelitian adalah limbah padat koyoran dan bulu hasil proses penyamakan kulit di Unit Pelaksana Teknis (UPT) Industri Kulit dan produk Kulit Magetan sebanyak $1000 . \mathrm{Kg}$ yang akan diproses menjadi pupuk kompos organik.

Hasil penelitian didapatkan kandungan $\mathrm{N}, \mathrm{P}$ dan $\mathrm{K}$ sebelum dan setelah perlakuan fermentasi pupuk organik: Unsur $\mathrm{N}$ sebelum perlakuan $0,583 \%$, setelah perlakukan fermentasi pada hari ke 21 unsur $1,483 \%$. Unsur $P$ sebelum perlakuan $0,521 \%$, setelah perlakukan fermentasi pada hari ke 21 unsur $0,11 \%$. Unsur K sebelum perlakuan 3,241 \%, setelah perlakukan fermentasi pada hari ke 21 unsur 3,623\%. Berdasar Permen Pertanian RI No: 28/permentan/SR.130/5/2009 tgl 22 Mei 2009 kadar unsur N, P dan K pada pupuk organik lebih kecil sama dengan $2 \%$.

Pupuk organik mengandung unsur-unsur hara yang dibutuhkan untuk pertumbuhan, perkembangan, kesehatan tanaman. Unsur-unsur hara itu terdiri dari: Unsur Nitrogen $(\mathrm{N})$, untuk pertumbuhan tunas, batang dan daun. Unsur Phosphat (P) untuk merangsang pertrumbuhan akar, buah dan biji.

Kesimpulan setelah dibandingkan dengan Ketentuan Permen Pertanian RI No: 28/permentan/SR.130/5/2009 tgl 22 Mei 2009 kandungan N, P dan K maka dapat disimpulkan bahwa untuk unsur $\mathrm{N}$ dan $\mathrm{P}$ sudah memenuhi sayarat sedangkan unsur $\mathrm{K}$ melebihi syarat. Saran sampaikan untuk penelitian selanjutnya dapat dilakukan penelitian dengan bahan baku yang sama akan tetapi permasalah yang diteliti bagaimana menurunkan unsur $\mathrm{K}$ agar kompos memenuhi syarat sebagai pupuk organik.
\end{abstract}

Kata Kunci : unsur hara, kompos, pupuk organik.

\section{PENDAHULUAN}

Unit Pelaksana Teknis (UPT) Industri Kulit dan produk Kulit Magetan menampung 35 perusahaan dan 115 pengrajin penyamak kulit, dari proses ini dihasilkan limbah padat dalam bentuk koyoran dan bulu dalam jumlah yang yang cukup besar. Karakteristik limbah tersebut tidak mudah terurai, berbau spesifik sehingga cukup mengganggu lingkungan sekitar yang berdampak terhadap protes masyarakat. Badan Lingkungan Hidup Kabupaten Magetan dan Institusi terkait harus bertanggung jawab untuk melakukan pembinaan agar permasalahan yang terjadi tidak semakin meluas.

Untuk mengatasi permasalahan ini kami Tim peneliti dari Prodi Kesling Kampus Magetan berinisiatip melakukan uji coba yaitu koyoran yang dihasilkan dibuat kompos/pupuk organik. Dari hasil penelitian ini, harapannya akan dapat membantu memecahkan permasalahan yang ada. Pelaksanaan penelitian ini melibatkan petani agar nantinya pupuk kompos yang dihasilkan dapat dimanfaatkan oleh petani dan mendorong petani untuk mau membuat pupuk kompos tersebut secara mandiri. .Pada akhirnya limbah koyoran dan bulu yang sejak berdirinya Unit Pelaksana Teknis (UPT) Industri Kulit dan produk Kulit Magetan menjadi masalah di lingkungan menjadi bahan yang dibutuhkan masyarakat petani disekitarnya dan permasalahan pencemaran lingkungan teratasi.

Penelitian ini bertujuan untuk mengetahui cara mengolah limbah padat kulit (koyoran dan bulu) menjadi pupuk organic sebagai solusi pemecahan masalah pencemaran lingkungan. Untuk mengetahui hasil dilakukan uji terhadap kandungan unsur N, $P$ dan $K$ sebelum dan sesudah proses pembuatan pupuk organik. 


\section{METODE PENELITIAN}

a. Jenis Penelitian: Ini adalah penelitian Eksperimen, dengan uji-coba pembuatan kompos organik dari bahan baku koyoran dan bulu limbah pengolahan kulit, yang diolah secara fermentasi dengan bantuan mikroorganisme untuk mempercepat proses dekomposisi.

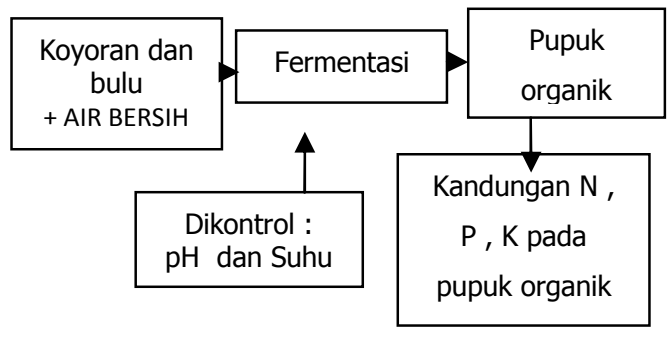

Gambar 1. Kerangka Konsep Penelitian

b. Populasi dan Sampel

Populasi penelitian adalah limbah padat koyoran dan bulu hasil proses penyamakan kulit di Unit Pelaksana Teknis (UPT) Industri Kulit dan produk Kulit Magetan.

Sampel penelitian adalah limbah padat koyoran dan bulu hasil proses penyamakan kulit di Unit Pelaksana Teknis (UPT) Industri Kulit dan produk Kulit Magetan sebanyak $1000 \mathrm{Kg}$ yang akan diproses menjadi pupuk kompos organik.

c. Tempat dan Waktu Penelitian.

Tempat Penelitian dilakukan di Unit Pelaksana Teknis (UPT) Industri Kulit dan produk Kulit Magetan.

Waktu penelitian dilaksanakan selama 12 Minggu tahun 2014 dimulai pada bulan September hingga Nopermber 2014 secara rinci dapat di baca pada jadwal penelitian.

d. Variabel Penelitian: Kandungan Nitrogen,Kandungan Phosphat, dan Kandungan Kalium e. Analisis data: Analisis data dengan membandingkan, kandungan $\mathrm{N}, \mathrm{P}$ dan $\mathrm{K}$ yang ada pada koyoran dan bulu sebelum dan sesudah proses fermentasi

\section{HASIL PENELITIAN}

Hasil pengamatan suhu Koyoran dan bulu sebelum perlakuan $29^{\circ} \mathrm{C}$ (suhu kamar) dan dalam proses fermentasi meningkat menjadi $55^{\circ} \mathrm{C}$ kemudian turun hingga $32^{\circ} \mathrm{C}$ setelah 21 hari. Sebelum perlakuan Koyoran dan bulu bersifat basa ( $\mathrm{pH} \mathrm{10,3)}$ dan setelah proses pematangan (fermentasi) menjadi normal ( $\mathrm{pH} 7,1)$. Bau Koyoran dan bulu sebelum perlakuan sangat menyengat khas pembusukan daging, namun selama proses fermentasi 14 hari hingga 21 hari bau tersebut berangsur-angsur berkurang dan berbau fermentasi.

Data hasil pengukuran kadar Pupuk Organik sebelum perlakuan dan sesudah perlakuan 7 hari, 14 hari dan 21 hari menunjukkan bahwa Nitrogen dalam N Total (\%) ada kenaikan. Sedang kandungan Phospor (\%) ada penurunan dan kandungan Kalium (\%) ada indikasi kenaikan. Secara terinci dapat dilihat dalam tabel tersebut di bawah ini

Tabel 1. Kandungan N, P, K Pupukorganik sebelum dan Sesudah fermentasi pada hari ke-7 s/d ke-21.

\begin{tabular}{|c|l|c|c|c|c|}
\hline \multirow{2}{*}{ No } & \multirow{2}{*}{ Para meter } & \multicolumn{4}{|l|}{ Kadar dalam \% } \\
\cline { 3 - 6 } & & & \multicolumn{4}{|c|}{ Stl Perlakuan } \\
\cline { 3 - 6 } & & \multirow{2}{*}{\begin{tabular}{c} 
Sebe \\
\cline { 3 - 6 }
\end{tabular}} & & \multicolumn{3}{|c|}{$7 \mathrm{hr}$} & $14 \mathrm{hr}$ & $21 \mathrm{hr}$ \\
\hline 1 & $\mathrm{~N}(\%)$ & 0,583 & 0,876 & 1,241 & 1,483 \\
\hline 2 & $\mathrm{P}(\%)$ & 0,521 & 0,33 & 0,09 & 0,11 \\
\hline 3 & $\mathrm{~K}(\%)$ & 3,241 & 3,521 & 3,612 & 3,623 \\
\hline
\end{tabular}

Sumber: Data Primer 


\section{PEMBAHASAN}

Karakteristik fisik Pupuk Organik dari bahan Koyoran dan Bulu. Koyoran dan Bulu dengan perlakuan fermentasi $7 \mathrm{~s} / \mathrm{d} 21$ hari untuk membuat Pupuk Organik diperoleh hasil sebagai berikut :

\section{a. Tekstur:}

Tekstur pupuk organik sebelum perlakuan Kuning kecoklatan dan setelah perlakuan 7 hingga 21 hari menunjukan tekstur ber ubah dari putih menjadi coklat kehitam-hitaman. Hal ini dapat diketahui bahwa setelah perlakuan selama 21 hari Proses fermentasi berjalan dengan baik hingga pupuk organic menjadi sempurna/matang.

b. $\mathbf{p H}$

Pupuk organik sebelum perlakuan nilai pH mencapai 10,5 dan setelah perlakuan 7 s/d 21 hari selama fermentasi menunjukan penurunan hingga $\mathrm{pH} 7,1$. Tingginya $\mathrm{pH}$ diawal proses diakibatkan kandungan kapur pada proses penyamakan yang berlebih dari agar proses dapat berjalan dengan baik perlu dilakukan penambahan asam sulfat hingga $\mathrm{pH}$ mendekati netral.

\section{c. Suhu}

Dari pengamatan suhu sebelum perlakuan $\left(29^{0} \mathrm{C}\right)$ dan selama proses fermentasi menunjukan ada kenaikan hingga $55{ }^{\circ} \mathrm{C}$. Setelah mendekati hari ke 21 suhu menurun hingga $32{ }^{\circ} \mathrm{C}$ dan hal ini sesuai pendapat Nyoman P.Aryoman, $d k k_{,}$(2010) mengatakan panas dihasilkan dari proses metabolisme mikroba. Peningkatan suhu dapat terjadi secara cepat dalam tumpukan kompos yang berkisar antara $30-60^{0}$ C. Kondisi semacam ini juga berarti bahwa proses pematangan sedang berlangsung secara optimal.

Kelembaban memegang peran penting dalam metabolisme mikroba. Kelembaban dengan kisaran 40 - $60 \%$ merupakan kisaran optimum bagi metabolisme mikroba. Suhu dan kelembaban pada proses fermentasi pupuk organik diperlukan untuk membantu proses metabolisme mikroorganisme pengurai sehingga fermentasi terjadi sempurna.

\section{d. Bau}

Bau menyengat khas bau busuk sebelum perlakuan dan setelah perlakuan semakin lama semakin berkurang hingga mendekati hari ke 21. Adapun munculnya bau menunjukan proses fermentasi sedang berlangsung dan jika sudah mendekati pematangan maka bau akan berkurang dan siap digunakan.

Pengomposan yang matang bisa diketahui dengan memperhatikan keadaan bentuk fisiknya, dimana fermentasi yang berhasil ditandai dengan adanya bercak-bercak putih pada permukaan koyoran dan bulu yang dihasilkan dari proses ini akan berwarna hitam kecoklatan.

Data Hasil pengukuran kandungan Nitrogen pada Pupuk Organik dengan Perlakuan 7 hari, 14 hari dan 21 hari menggunakan EM-4 yang telah dibiakkan selama 7 (tujuh) hari kandungan Nitrogen sebesar 0,876 \% sudah memenuhi syarat Peraturan Menteri Pertanian RI No. 28/permentan/SR.130/5/2009 yaitu $<2$ artinya pupuk organik dari bahan baku Koyoran dan Bulu tersebut bisa digunakan langsung sebagai pupuk Nitrogen bagi tanaman. Adapun perlakuan 14 hari kandungan Nitrogen menjadi 1,241 \% dan 21 hari kandungan Nitrogen 1,483 \% menunjukan ada peningkatan .

Penggunaan EM-4 yang mengandung bakteri pengikat Nitrogen pada proses pematangan pupuk organik ini sangat membantu mendongkrak peningkatan kandungan Nitrogen. Menurut Lartansuphaphol (2009), EM-4 mengandung bakteri Rhodo pseudomonas $s p$ yang mampu meningkatkan kandungan $\mathrm{N}$ pada pembuatan Pupuk.

Meningkatnya kandungan Nitrogen yang semakin tinggi maka mikroba akan menggunakan sebagai nutrisi untuk mensintesis protein sehingga penguraian berjalan cepat.(Yulianto A.B. dkk,2010).

Mengapa unsur-unsur Nitrogen (N) harus ada pada tanah pertanian, keberadaan unsur Nitrogen sangat dibutuhkan oleh tanaman karena dapat berfungsi sebagai:

a. Merangsang pertumbuhan tanaman secara keseluruhan

b. Merupakan bagian dari sel (organ) tanaman itu sendiri

c. Berfungsi untuk sintesa asam aminodan protein dalam tanaman

d. Merangsang pertumbuhan vegetatif (warna hijau daun, panjang daun, lebar daun) dan pertumbuhan vegetatif batang (tinggi dan ukuran batang).

e. Tanaman yang kekurangan unsur nitrogen gejalanya: pertumbuhan lambat/kerdil, daun hijau kekuningan, daun sempit, pendek dan tegak, daundaun tua cepat menguning dan mati. 
Kandungan Phospor pada Pupuk Organik dengan Perlakuan 7 hari, 14 hari dan 21 hari Kandungan phospor pada pupuk organik sebelum perlakuan 0,521 \% dan setelah ada perlakuan fermentasi dan fermentasi menggunakan EM-4 selama berturut-turut 7 hari hingga 21 hari $(0,11 \%)$ menunjukan angka penurunan. Kandungan

Phospor 0,11 \% ini masih memenuhi syarat Peraturan Menteri Pertanian RI No. 28/permentan/SR.130/5/2009 yaitu < 2 artinya pupuk organik tersebut bisa digunakan langsung sebagai pupuk Nitrogen bagi tanaman.

Penurunan kandungan Phospor selama proses fermentasi terjadi karena Phospor dalam garam-garam Phospat dibutuhkan sebagai nutrisi hara makro untuk pertumbuhan bakteri (ningrum, F, mustika,2012).

Penurunan kandungan Phospor disebabkan adanya proses pengikatan Phospor oleh mikroorganisme yang berasal dari bioaktivator EM-4 saat fermentasi (Dirjen IKM,2007)

Kandungan Phospor dalam Pupuk Organik yang digunakan untuk pemupukan tanaman berperan dalam proses penyimpanan dan pemindahan energi untuk sintesis karbonhidrat, protein dan proses fotosintesis. (Poerwowidodo,1992)

Upaya untuk meningkatkan kandungan $\mathrm{P}$ pada pupuk, saat proses pembuatan pupuk organik dapat ditambahkan bahan yang kaya kandungan P seperti tepung tulang (Prariesta dan Winata, 2009).

Fungsi unsur-unsur hara makro Fosfor $(P)$ :

a. Berfungsi untuk pengangkutan energi hasil metabolisme dalam tanaman

b. Merangsang pembungaan dan pembuahan

c. Merangsang pertumbuhan akar

d. Merangsang pembentukan biji

e. Merangsang pembelahan sel tanaman dan memperbesar jaringan sel

f. Tanaman yang kekurangan unsur fosfor gejalanya: pembentukan buah/dan biji berkurang, kerdil, daun berwarna keunguan atau kemerahan

Kandungan Kalium pada Pupuk Organik dari pupuk organik dengan Perlakuan 7 hari, 14 hari dan 21 hari. Berdasarkan tabel 5.2. kandungan Kalium sebelum perlakuan 3,241 $\%$. dan setelah perlakuan fermentasi dan fermentasi ada perbedaan yaitu menjadi $3,521 \%$ hari ke 7, dan 3,612 \% hari ke 14 dan 3,623\% ke 21 hari. Kandungan Kalium ini masih memenuhi syarat Peraturan Menteri Pertanian RI No.
28/permentan/SR.130/5/2009 yaitu $<2$ artinya pupuk organik tersebut bisa digunakan langsung sebagai pupuk Nitrogen bagi tanaman.

Peningkatan kandungan Kalium setelah perlakuan dapat terjadi karena hasil pelapukan melepaskan ion $\mathrm{K}^{+}$dari pertukaran kation dan dekomposisi bahan organik yang terlarut dalam pupuk

Koyoran . (Sumarno,2011) EM-4 mengandung bakteri Rhodopseudomonas $s p$ yang mampu meningkatkan kandungan $\mathrm{K}$ pada pembuatan Pupuk Organik .

Keberadaan kalium dalam pupuk Organik akan berperan penting dalam setiap proses metabolisme tanaman yaitu dalam sintesis asam amino, protein, karbohidrat dan gula. Kalium juga berperan dalam memperkuat tubuh tanaman agar daun dan bunga buah tidah mudah gugur. Kalium juga membantu pengangkutan gula dari daun ke buah dan umbi. Kalium juga merupakan sumber kekuatan bagi tanaman dalam menghadapi kekeringan dan penyakit. (Poerwowidodo, 1992).

Pupuk organik mengandung unsur-unsur hara yang dibutuhkan untukpertumbuhan, perkembangan, kesehatan tanaman. Unsurunsur hara itu terdiri dari: Unsur Nitrogen $(N)$, untuk pertumbuhan tunas, batang dan daun. Unsur Fosfor $(P)$, untuk merangsang pertumbuhan akar buah dan biji. Unsur Kalium (K) untuk mengingkatkan ketahanan tanaman terhadap serangan hama dan penyakit.

Dengan menggunakan hara, tanaman dapat memenuhi siklus hidupnya. Fungsi hara tanaman tidak dapat digantikan oleh unsur lain dan apabila tidak terdapat unsur hara tanaman, kegiatan metabolisme akan terganggu atau b erhenti sama sekali.Disamping itu umumnya tanaman yang kekurangan atau ketidakadaan suatu unsur hara akan menampakkan gejala pada suatu organ.

Pupuk adalah pupuk yang berbentuk organik an, dibuat dengan cara melarutkan kotoran ternak, daun jenis kacang-kacang dan rumput jenis tertentu ke dalam air. Pupuk organik mengandung unsur-unsur hara yang dibutuhkan untuk pertumbuhan, perkembangan,kesehatantanaman. Unsurunsur hara itu terdiri dari: Unsur Nitrogen $(\mathrm{N})$, untuk pertumbuhan tunas, batang dan daun. Unsur Fosfor $(P)$, untuk merangsang pertumbuhan akar buah, dan biji. Unsur Kalium (K), untuk meningkatkan ketahanan tanaman terhadap serangan hama dan penyakit. Pupuk ini memiliki keistimewaan yaitu pupuk ini dibanding dengan pupuk 
alam yang lain (pupuk kandang, pupuk hijau dan kompos) lebih cepat diserap tanaman.

\section{KESIMPULAN}

Karakteristik kandungan Nitrogen ( $\mathrm{N}$ total) pada awal 0,583\%, setelah fermentasi yang ke 21 hari menjadi 1,483\% masih memenuhi sebagai pupuk organic

Karakteristik kandungan Phospat $(P)$ pada awal 0,521 \%, setelah fermentasi yang ke 21 hari menjadi $0,11 \%$ masih memenuhi sebagai pupuk organic

Karakteristik kandungan Kalium (K) pada awal 3,241 \%, setelah fermentasi yang ke 21 hari menjadi 3,623\% kurang memenuhi sebagai pupuk organic

Setelah dibandingkan dengan Permen Pertanian RI No:28/Pertan/SR.130/5/2009 tgl 22 Mei 2009 kandungan N, P, dan K untuk unsur $\mathrm{N}$ dan $\mathrm{P}$ sudah memenuhi syarat, sedangkan unsur $\mathrm{K}$ melebihi syarat yaitu diatas $2 \%$.

\section{SARAN}

Perlu penelitian lebih lanjut tentang waktu fermentasi yang efektif dan efisien, tentang komposisi yang tepat antara EM-4, nutrien bakteri, volume bahan baku agar mampu meningkatkan kandungan Nitrogen, Phospor, Kalium dan parameter lain sesuai dengan Peraturan Menteri Pertanian RI Nomor: 28/permentan/SR.130/5/2009

\section{DAFTAR PUSTAKA}

Arikunto, P. D. S. 2005. Manajemen Penelitian, Jakarta, PT. RINEKA CIPTA, Jakarta.

Peraturan Pemerintah Nomor 21/PTM/2006 Tentang Kebijakan Dan Strategi Nasional Pengembangan Sistem Pengelolaan Persampahan.

Peraturan Pemerintah Nomor 81 Tahun 2012 Tentang Pengelolaan Sampah Rumah Tangga Dan Sampah Sejenis Sampah Rumah Tangga.

Susanto, Nugroho 2010. Besar Sampel Dalam Penelitian Kesehatan, dG books, Yogyakarta

Lartansuphaphol, $\mathrm{T}$ and Jitumroonchokchai, $\mathrm{P}$ ,2009, Effectiveness of Bacteria and fungi inoculants in liquid organik Fertilizer production. Asia journal of food and agro industry. 169-174

Ningrum, F, mustika, 2012, Faktor-faktor yang mempengaruhi pertumbuhan bakteri,

http/www.scribd.com/doc/94884056/Fakt or-faktor yang mempengaruhi pertumbuhan bakteri.

Permen pertanian RI no. 28/perntan/SR.130/5/2009 tentang : Pupuk organik, pupuk hayati dan pembenah tanah.

Poerwowidodo, 1992, Telaah kesuburan tanah, Penerbit Angkasa, Bandung.

Sumarno, 2011, Pupuk dan Unsur hara Tanaman, FPUB. 